\title{
大阪府南部の生活排水が流入する河川における ヤゴの生息限界について \\ LIVING LIMIT OF LARVA OF DRAGONFLY IN RIVERS WITH DOMESTIC SEWAGE INFLOW IN THE SOUTHERN PART OF OSAKA
}

\author{
横田恭平 1 ・井伊博行 2 . 養父志乃夫 3 . 平田健正 4 \\ Kyohei YOKOTA,Hiroyuki II,Sinobu YABU,Tatemasa HIRATA
}

\begin{abstract}
1学生会員 和歌山大学大学院 システム工学研究科 (广 640-8510 和歌山市栄谷930番地)
2正会員 博(理) 和歌山大学 システム工学部環境システム学科 (广 640-8510 和歌山市栄谷930番地)

3正会員 農博 和歌山大学 システム工学部環境システム学科 (广 640-8510 和歌山市栄谷930番地)

4正会員 工博 和歌山大学 システム工学部環境システム学科 († 640-8510 和歌山市栄谷930番地)
\end{abstract}

\begin{abstract}
Living limits about $\mathrm{Na}^{+}$and $\mathrm{Cl}^{-}$concentrations of larva of dragonfly were studied. $\mathrm{As}^{+}{ }^{+}$and $\mathrm{Cl}^{-}$concentrations in river water increased, the number of larva decreased and species composition of larva changed from Stylogomphus suzukii to Calopterx atrata. $\mathrm{Na}^{+}$and $\mathrm{Cl}^{-}$concentrations were thought to be mixing ratio of domestic sewage and domestic sewage was thought to contain toxic substance. Davidius nanus was distributed widely in the river water from low to high mixing ratio of domestic sewage. Living limits of maximum $\mathrm{Na}^{+}$and $\mathrm{Cl}^{-}$ concentrations for Calopterx atrata and Davidius nanus were 50 and $80 \mathrm{mg} / \mathrm{l}$. The values were living limit of all larva of dragonfly observed in the southern part of Osaka. In the long term, the living limits of maximum $\mathrm{Na}^{+}$and $\mathrm{Cl}^{-}$concentrations for larva of dragonfly were 38 and $59 \mathrm{mg} / \mathrm{l}$. When anionic surface active agent is 3.8 to $6.2 \mathrm{mg} / \mathrm{l}$, larva of dragonfly disappeared.
\end{abstract}

Key Words : larva of dragonfly, domestic sewage, living limit, $\mathrm{Na}^{+}, \mathrm{Cl}^{-}$, anionic surface active agent

\section{1.はじめに}

河川における生物の減少原因は, 一般的には, 河川周 辺から流出する家庭排水をはじめとした污染物質の流出 と河川改修による自然環境の変化であると考えられてい る. 河川への污染物質の混入は, 下水道整備力淮んてい る現在 , 年々減少している.河川は, 1997年の河川法の 改正により，自然状態に戻りつつある．1990年代以前の 河川法では, 治水, 利水を目的に河川整備がなされてき

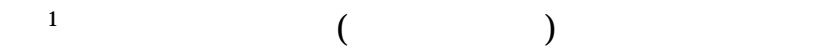
れた多自然型川づくりにより，生物の良好な生育環境に 配慮し，あわせて美しい自然景観を保全，あるいは創出 する事業が河川で，実施されるようになってきた .この ため，1997年の河川法の改正では，河川環境の整備か泪 的に追加された . 生物の多くは , 河川の瀬や淵といった 変化に富んた場所に生息する ${ }^{2)}$.このことから多自然型 川づくりにおいて , ビオトーブ3)や自然護岸といった河 川改修を行ってきている.このような努力にもかかわら ず生態系が自然状態に戻らない地域も存在する . その多 くは，住宅や工場の密集地域で, 生活排水や工場排水の
ため, 水質の悪化が生物の減少の要因になっていると考 えられる. 現在, 生物数・生物種と水質との関係では, 水質指標としてBODが用いられている．しかし，BOD は流下中に有機物が分解するため変動し, 必ずしも生活 排水量と比例関係にない(4) 5)．光のため，これまでの基 準であるBODは，生活排水の割合を推定することはでき ない, 乥こで, 本研究ては, 大阪府南部の河川において, 河川周辺の人口か下流に行くにつれ増加し, 生活排水量 の割合か高くなっている大津川水系6)，石川水系7)，下 流においても人口増加の少ない番川と大川で, 生活排水 の影響が生物の生息分布や種構成にどれだけ影響を与え るの力調べた . 水質指標としては, 雨水や森林からの沢 水に比へ甡活排水に多く含まれ生活排水量の目安となる $\mathrm{Na}^{+}, \mathrm{Cl}^{\text {濃度 }}{ }^{8}$ を用いた .さらに , 大津川水系において は, 生活排水に含まれ, かつ生物生息に影響を与えると 考えられる陰イオン界面活性斉の影響も調べた . 生物指 標としては，(1)成虫になるまで水の中で生活し水質環境 に影響を受けること，(2)同定がしやすいこと，(3)成虫に なるまで2年以上かかる種類が存在し，長期的な水質環 境の影響をうけることから，流水性のトンボの幼虫であ るヤゴを用いた 。 


\section{2. 調査地, 水質調査・分析, 生物調査の概要}

調査地点は，図一1に示したとおり，大阪府南部地域に 広がる大津川水系の槇尾川・父鬼川9 , 大和川支流の石 川水系である石川・千早川・石見川，番川，大川の計7 河川である . 大津川水系の特徵は , 下流に行くにつれ河 川周辺に住宅地か昿がることである . また上流から河口 $15 \mathrm{~km}$ 付近まで市街化調整区域のため，下水道整備が行 われていない，石川流域の特徵は，石川と石見川の合流 地点に住宅集合地があり，光の後下流に行くに従い住宅 地は減少するが，千早川合流地点から住宅地が多くなる。 番川・大川の特徵は, 上流から下流まで河川周辺人口が 他の2水系に比べて少ないため, 污濁負荷量か比較的少 ない。

本研究では水質調査と生物調査を行った . 水質調査は, 大津川水系においては，不定期であるが，2004年4月19 日に上流(地点3,4)，5月7日に下流(地点8,9)，24日に上流 (地点2 4,8)，7月28日に上流(地点2 5,8)，8月4日に下流 (地点8,9)，10月17日に上流 下流(地点2 5,8,9)，10月29日 に上流 下流(地点1 9)，12月1日に下流(地点8,9)，23日に 上流(地点1 5,8)，29日に上流(地点1,2,4,8,9)の調査を行っ た .さらに陰イオン界面活性斉測定のため，2005年9月2 日に上流 下流(地点1 6,8,9)の調査を行った . 調査地点 と水質調査日の詳細は, 表-1に丸記号として揭載してい る.地点8ては，2004年4月15日から現在(2005年9月30日) までほぼ毎日，水質調査を行った．また，番川は，11月 21日に下流の地点21-2て水質調査を行った . 水質調査と 生物調査を同時に行った日は，2004年11月17・21日に番 川(地点18 21-2)，12月11・19日に大川(地点23 27), 23 ・28日に大津川水系の 2 河川(地点1 9)，2005年2月24 日・3月13日に石川水系の3河川(地点10 17)であり，す ベてのトンボがヤゴでいる期間に一致している .

水質調査では, サンプル採取時に, $\mathrm{pH}$ ，電気伝導度 (EC)，酸化還元電位 $(\mathrm{ORP})$ ，溶存酸素量 $(\mathrm{DO})$ の 測定も行っている・pH計, EC計, ORP計は, HORIBA 社のD-22，D-23を使用している．DO計(F102)は， Iijima 社を使用している.採水サンプルは, 研究室に持ち帰り， $0.45 \mu \mathrm{m}$ のフルターを通したあと，溶存成分をイオンク ロマトグラフィーで分析した .イオンクロマトグラ フィーは，(株) 日本ダイオネクス社製を使用している． 陰イオン界面活性斉測定は, 比色法により, 吸光光度計 (DR/2500，HACH製) を用いて分析を行った。

生物調査地点は, 対象の河川においてヤゴか星息して いると考えられる瀬や淵などか存在する場所を選定した . 調査地点の大きさは，流下方向に約50m行った . しかし， 調査地の河川か狭い場所に関しては，10 20mの範囲で 行った場所もある.生物調査は, 約 30 分の間に3名（内 専門家1名) て網による採取を行った．同定項目は, ヤ ゴの種類, 頭数 , 大きさ , 成虫までの年である .
調査地点

地点1 9: 大津川水系 地点10～17: 石川水系 地点18〜21- $2:$ 番川

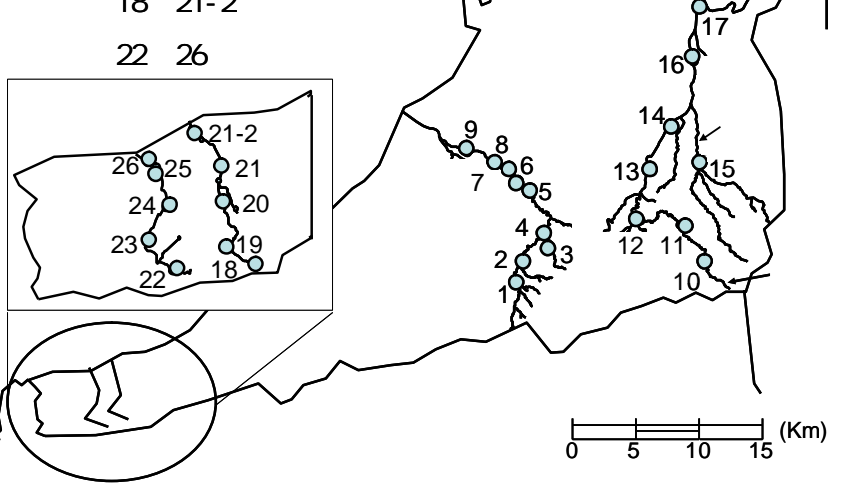

図-1 調查対象地域

表- 1 大津川水系の水質調査日

\begin{tabular}{|c|c|c|c|c|c|c|c|c|}
\hline \multirow{2}{*}{ 水質調査日 } & \multicolumn{8}{|c|}{ 地点 } \\
\hline & 1 & 2 & 3 & 4 & 5 & 6 & \begin{tabular}{l|l|}
7 & $\varepsilon$
\end{tabular} & \begin{tabular}{l|l}
8 & 9
\end{tabular} \\
\hline $2004 / 4 / 19$ & & & & & & & & \\
\hline $5 / 7$ & & & & & & & & \\
\hline $5 / 24$ & & & & $\overline{0}$ & & & & \\
\hline $7 / 28$ & & $D$ & & O & O & & & \\
\hline $8 / 4$ & & & & & & & & \\
\hline $10 / 17$ & & & & & & & & \\
\hline $10 / 29$ & & & & & & & & \\
\hline $12 / 1$ & & & & & & & & 0 \\
\hline $12 / 23$ & & & & 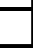 & 0 & & & \\
\hline $12 / 29$ & & & & O & & & & $\underline{0}$ \\
\hline $005 / 9 / 2$ & & D & OI & 0 & O & $\overline{\mathrm{O}}$ & & $\mathrm{O} O$ \\
\hline
\end{tabular}

3. $\mathrm{Na}^{+}, \mathrm{a}^{-}$濃度からみたヤゴの生物生息限界

図-2は各水系 , 各河川におけるヤゴの総数と $\mathrm{Na}^{+}, \mathrm{Cl}$ 濃度との関係を示す .ここで, $\mathrm{Na}^{+}, \mathrm{Cl}^{-}$濃度は, 主に生 活排水に起因し，生活排水量の指標となる . 全体として は, $\mathrm{Na}^{+}, \mathrm{Cl}$ 濃度が上昇すると，ヤゴの総数は減少する． しかし，大津川水系の上流部においては，逆に $\mathrm{Na}^{+}$, Cl濃度が上昇するとヤゴの総数も増加している .ヤゴの 総数が最も減少しているときのNa ${ }^{+}$濃度は, 大津川水系 では24mg/l，石川水系では60mg/l，番川・大川では $10 \mathrm{mg} /$ /である . またヤゴの総数が最大になる時のNa+濃 度は, 大津川水系, 石川水系, 番川, 大川共通して $10 \mathrm{mg} / 1$ 付近である . 次にヤゴの総数が最も減少している ときのCl濃度は, 大津川水系で $30 \mathrm{mg} / \mathrm{l}$ ，石川水系で $100 \mathrm{mg} / \mathrm{l}$, 番川・大川で10mg/である.またヤゴの総数が 最大になる時のCl濃度は, 大津川水系, 石川水系, 番川, 大川共通して $10 \mathrm{mg} / 1$ 付近であった . 図-3は , ヤゴの種類 別頭数と $\mathrm{Na}^{+}$濃度との関係, 図-4に, ヤゴの種類別頭数 とCl濃度との関係を示す .ここでヤゴが偶然，流される 場合を除外するために，各種ヤゴにおいて2頭以上 

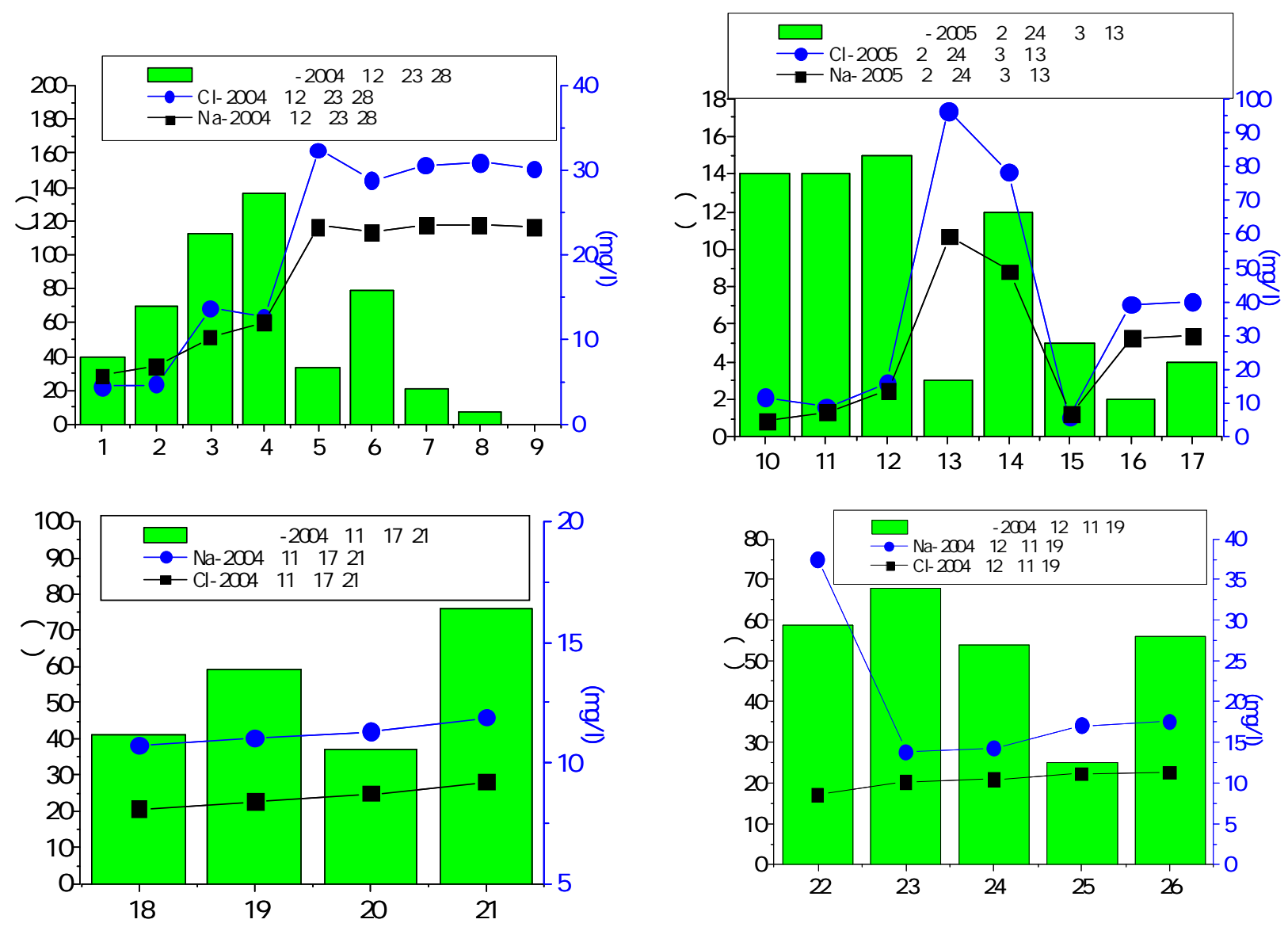

图-2 各水系, 各河川におけるヤゴの総数と $\mathrm{Na}^{+}, \mathrm{a}$
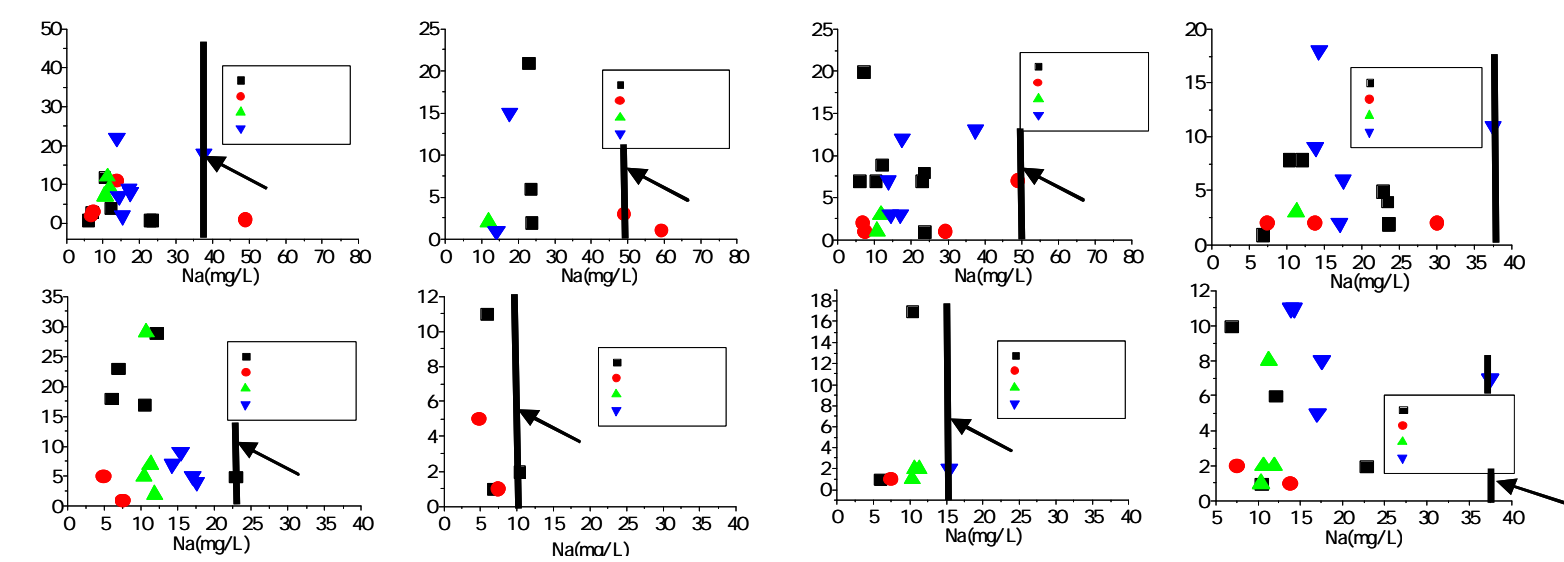

図- 3 ヤゴの種類別頭数と占゙濃度の関係
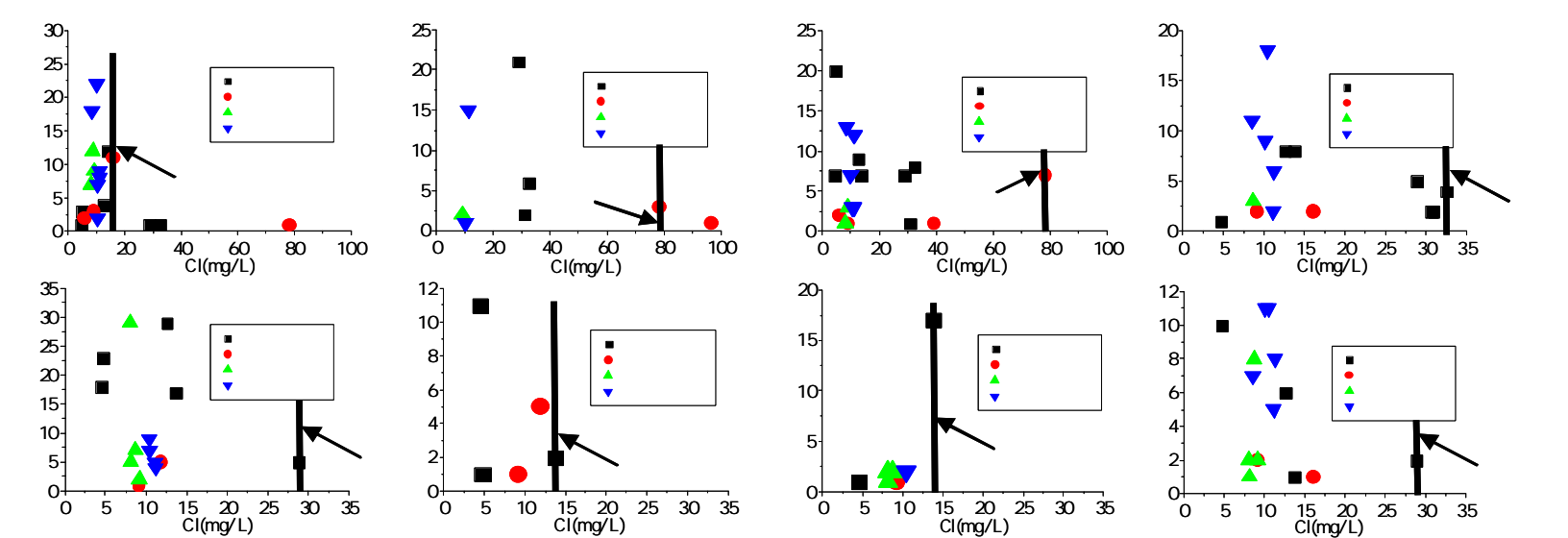

図-4 ヤゴの種類品臨数と “濃度の関係 
存在し, かつ濃度が一番高いときを生物生息限界濃度と 定義する . 図-5はこれらをまとめたものである .これに よると, クロサナエの生物生息限界の $\mathrm{Na}^{+}$濃度は $10 \mathrm{mg} / \mathrm{l}$, ミルンヤンマは $15 \mathrm{mg} / \mathrm{l}$, オジロサナエは $20 \mathrm{mg} / \mathrm{l}$, コオニ ヤンマ, ニシカワトンボ , ヤマサナエは $38 \mathrm{mg} / 1$, ダビド サナエ , ハグロトンボは $50 \mathrm{mg} /$ /である.クロサナエ , ミ ルンヤンマ , ニシカワトンボの生物生息限界のCl濃度は $15 \mathrm{mg} / \mathrm{l}$, ヤマサナエ , オジロサナエ , コオニヤンマは

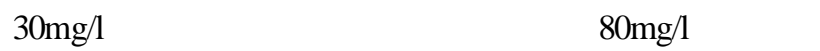
よって, $\mathrm{Na}^{+}$とClの関係からヤゴの種構成を「クロサナ エ」,「ミルンヤンマ」，「ニシカワトンボ」，「オジ ロサナエ」，「コオニヤンマ・ヤマサナエ」，「ハグロ トンボ・ダビドサナエ」のように大きく6つに分けるこ とができる .

以上のことから $, \mathrm{Na}^{+}, \mathrm{Cl}$ の生物生息限界濃度が一番 低いのは, クロサナエ , ミルンヤンマ , 中間がニシカワ トンボ , オジロサナエ , コオニヤンマ , ヤマサナエ , 一 番高いのはダビドサナエ , ハグロトンボであつた . 特に ハグロトンボは，濃度が高し場所でも生息できる．環境 基本法による生物指標は, 水質階級 I(きれいな水)では, ミルンヤンマ , ニシカワトンボ , オジロサナエ , 水質等 級川(少し污れた水)では, コオニヤンマ, ヤマサナエ, ダビドサナエ, ハグロトンボ 10) であることから, 生活 排水量の指標となる $\mathrm{Na}^{+}, \mathrm{Cl}$ 濃度の変化は, 従来の結果 と一致しており，生活排水がヤゴの生息限界に影響を与 えていることがわかった .

\section{4. $\mathrm{Na}^{+}, \mathrm{G}$-濃度によるヤゴの種構成の変化}

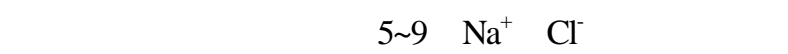
ないのにヤゴの総数か増減した . また地点1 4はNa ${ }^{+}$, $\mathrm{Cl}$ 濃度か増加し, ヤゴの総数か増加したことがわかった 。 そこでヤゴの総数だけでなく，種構成の変化を確認する ため, 図一に大津川水系の各地点におけるヤゴの種構成 を示す . 図-6のヤゴの頭数は，8種類しか載せていない ため, 図一2のヤゴの総数より少ない. 生物生息限界濃度 が最も低いクロサナエ , ミルンヤンマは, 地点1 3は生

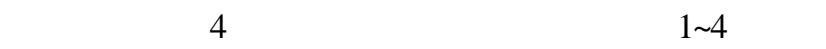
ジロサナエが優先種である. 生物生息限界濃度が一番高 いハグロトンボ, ダビドサナエは, 地点1 4では優先種 ではないが, 地点5，6では優先種になる .このことから， 地点6のヤゴの総数か増加した理由は, ハグロトンボ, ダビドサナエか地点1 4より増加したからといえる . ま た , オジロサナエが多く生息する地点4ではヤゴの総数 が多くなる. 光こで, この傾向が石川でも見られるかど うかを確忍するため, 図一右川水系の各地点のヤゴの 種構成を示す.地点10では, オジロサナエとクロサナエ が優先種であるが, $\mathrm{Na}^{+}, \mathrm{Cl}$ 濃度が徐々に増加すること によって , 地点12ではニシカワトンボとヤマサナエが優

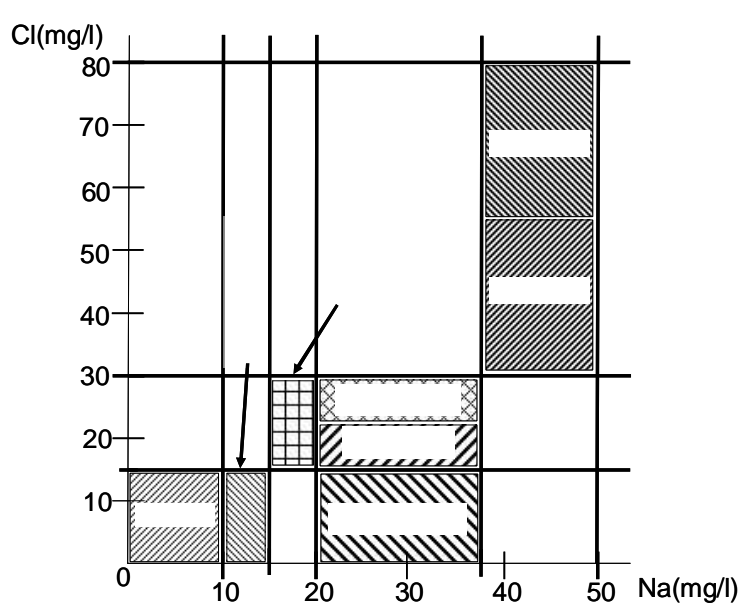

图 $5 \mathrm{Na}^{+}, \mathrm{a}$-濃度における各種ヤゴの生物生息限界

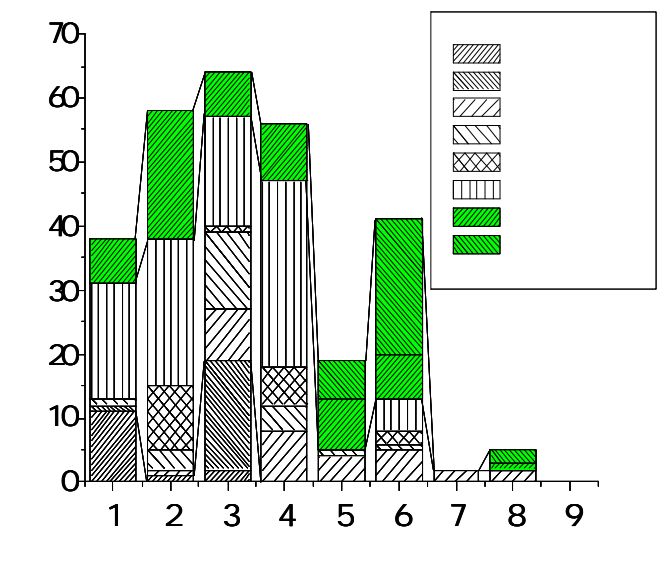

图-6 大津川水系の各地点におけるヤゴの種構成の変化

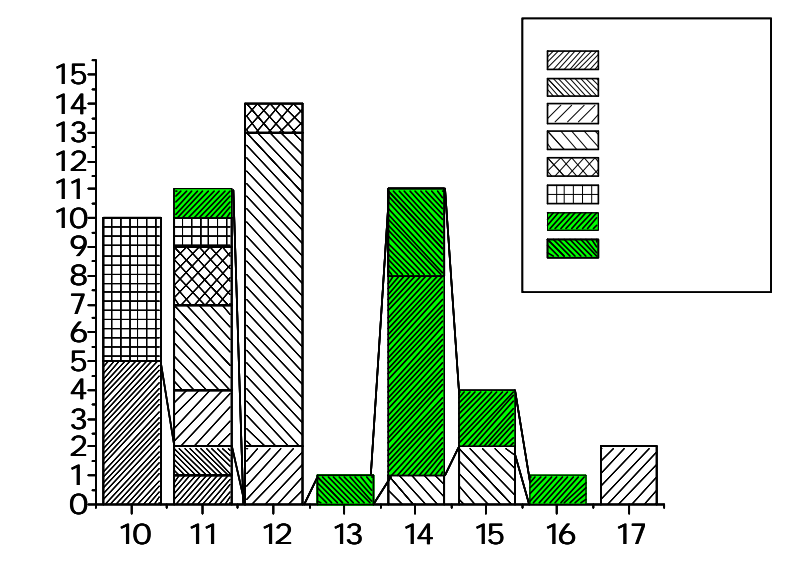

図-7 石川水系の各地点におけるヤゴの種構成の变化

先種に変化している.この地点10 12の変化は, 生物生 息限界濃度の低い種間の構成の変化である.地点13は， $\mathrm{Na}^{+}, \mathrm{Cl}$ 濃度が石川水系で最も高いため, 生物生息限界 濃度の最も高い々グロトンボしかいない . 地点14 15は， 水田からの水や支流の森林地点からの河川流入により， $\mathrm{Na}^{+}, \mathrm{Cl}^{-}$濃度は減少している。しかし $\mathrm{Na}^{+}, \mathrm{Cl}^{-}$濃度は地 点10 12より高いため, 生物生息限界の高いダビドサナ エとハグロトンボガ優先種となっている．よって，大津 川水系同樣に地点14のヤゴの総数は増加したが, 兴の内 わけは, 生活排水により而性のあるハグロトンボやダビ ドサナエか増加したためである。 


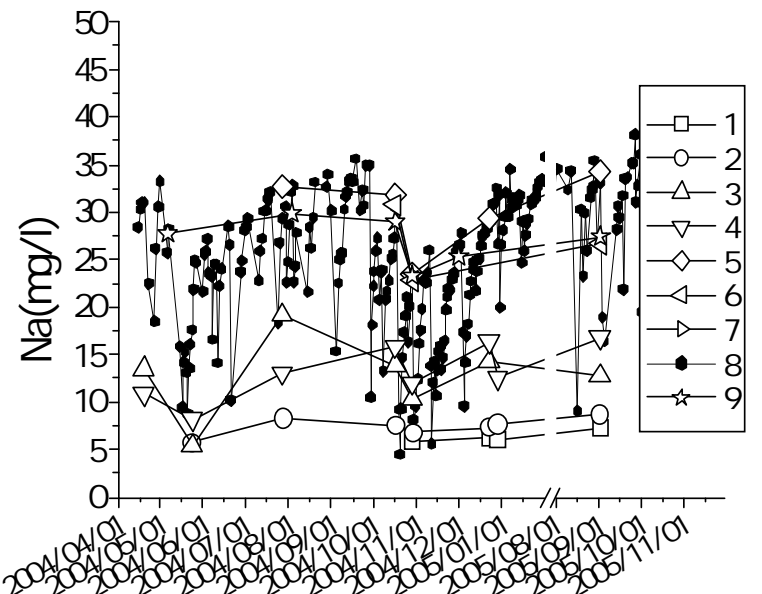

図-8 大津川水系のNa+濃度の年間の変化

\section{5. 大津川水系によるNa+,$a^{-}$濃度の年間変化と ヤゴの種構成}

生物調査したときの $\mathrm{Na}^{+}, \mathrm{Cl}$ 濃度とヤゴの総数, 種構 成には，関係があることがわかった .ただしこれは，生 物調査した時の $\mathrm{Na}^{+}, \mathrm{Cl}$ 濃度であるため, 年間変化をみ ると大きく変動している可能性がある.よってヤゴの種 構成と生活排水量の指標となる $\mathrm{Na}^{+}, \mathrm{Cl}$ の年間の濃度変 化との関係を考察していく.図-8，9に，大津川水系(地 点1 9)における $\mathrm{Na}^{+}, \mathrm{Cl}$ 濃度の年間の変化を示す . 調査 日は , 表-1に示している. 大津川水系全域の変化を把握 するため代表地点として, 地点8における毎日のデータ を示している.地点8は, 年間を通じての濃度の変動を 示しており，濃度が高くなる $\left(\mathrm{Na}^{+}\right.$の最大值が $38 \mathrm{mg} / \mathrm{l}$, $\mathrm{Cl}$ の最大值が59mg/l） のは，7月 9月の夏の時期である . また , 濃度か低くなる $\left(\mathrm{Na}^{+}\right.$の最小值が $5 \mathrm{mg} / \mathrm{l}, \mathrm{Cl}$ の最小 值が $4 \mathrm{mg} / \mathrm{l})$ のは， $6 ， 10 \sim 12$ 月の梅雨と秋の降雨の時期で ある

上流からみて地点 3 までは, クロサナエ , ダビドサナ 工か確認できた . 地点 3 の年間の濃度は, $\mathrm{Na}^{+}$の最小值が $5 \mathrm{mg} / \mathrm{l}$, 最大值が $19 \mathrm{mg} / \mathrm{l}, \mathrm{Cl}$ の最小值が $4 \mathrm{mg} / \mathrm{l}$, 最大值が 24mg/lである . また地点6までは, ニシカワトンボ , コ オニヤンマ , オジロサナエか確認できた . 地点6の年間 の濃度は, $\mathrm{Na}^{+}$の最小值か $23 \mathrm{mg} / \mathrm{l}$, 最大値か $31 \mathrm{mg} / \mathrm{l}, \mathrm{Cl}^{-}$ の最小值か $29 \mathrm{mg} / \mathrm{l}$, 最大值か $39 \mathrm{mg} / \mathrm{l}$ である.地点 8 までは， ヤマサナエ , ダビドサナエ , ハグロトンボか確認できた . 地点8の年間の濃度は, $\mathrm{Na}^{+}$の最小值か $5 \mathrm{mg} / \mathrm{l}$, 最大值が $38 \mathrm{mg} / \mathrm{l}, \mathrm{Cl}$ の最小值が $4 \mathrm{mg} / \mathrm{l}$, 最大值が59mg/lである. 図-10は , これらの関係を示したものである . 白抜きは 地点3, 格子は地点 6 , 斜線は地点8における $\mathrm{Na}^{+}, \mathrm{Cl}^{-}$濃 度の年間の変動幅である .このことから $, \mathrm{Na}^{+}, \mathrm{Cl}$ の年 間の濃度変化の違いからヤゴの種類を「クロサナェ・ミ ルンヤンマ」「ニシカワトンボ・オジロサナエ・コオニ

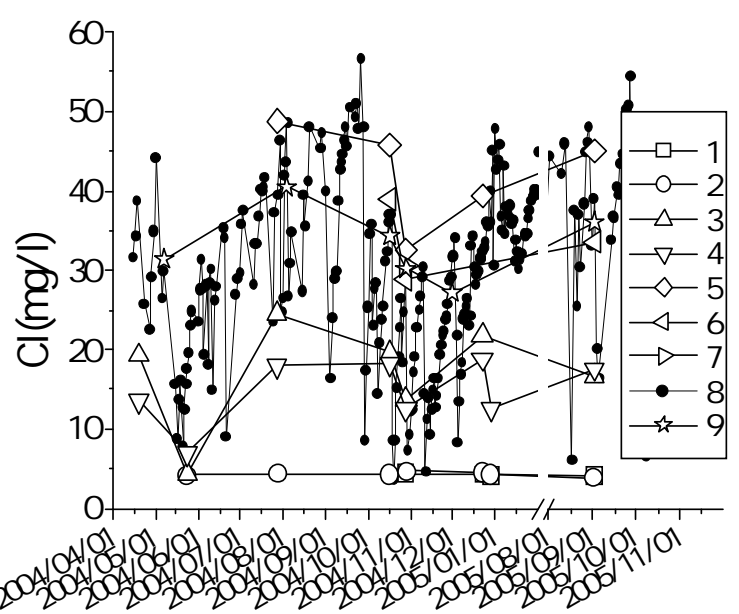

図 9 大津川水系のd濃度の年間の变化

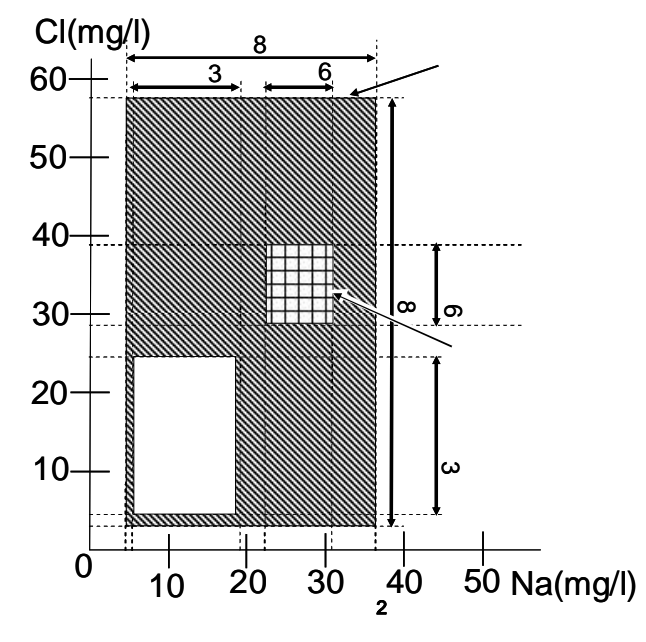

図-10 大津川水系の各地点におけるNa+ $a^{+}, a^{-}$濃度の

年間の最大值・最小值とヤゴの種構成

ヤンマ」「ヤマサナエ・ダビドサナエ・ハグロトンボ」 の大きく3つに分けることができた .

大津川水系においてヤゴの総数が最大になるのは，地 点4である. 地点 4 の年間濃度の最大值と最小值の変動幅 は, $\mathrm{Na}^{+}$か5 18mg/l , Clが5 17mg/l゙ある。

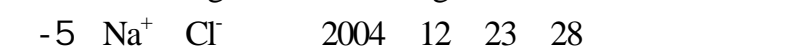
を行った時の值である . 図-100 $\mathrm{Na}^{+}, \mathrm{Cl}$ 濃度は，地点8 に関しては，2004年4月15日〜2005年9月30日，兴の他の 地点は表-1に示した調査日での值である．つまり，一時 的な水質の值と長期的な水質変化の值を用いてヤゴの生 息状況との比較をしている.この結果から，「クロサナ エ・ミルンヤンマ」, 「ニシカワトンボ・オジロサナ エ・コオニヤンマ」，「ダビドサナェ・ハグロトンボ」 は同じ傾向であるといえる .しかし「ヤマサナエ」は， 一時的な水質では，「コオニヤンマ」と同じ傾向にある が, 長期的な水質変化では, 「ダビドサナエ .八グロト ンボ」と同じ傾向にあるといえる . 


\section{6. 陰イオン界面活性斉收らみた生物生息限界}

生活排水量の指標となる $\mathrm{Na}^{+}, \mathrm{Cl}^{-}$から, 生活排水がヤ ゴ総数, 種構成に影響を与えていることがわかつた . こで生活排水のみに含まれ，水生生物に影響があると考 えられる ${ }^{11)}$ 陰イオン界面活性剂とヤゴとの関係を考察す る . 図-11は , 大津川水系にて2005年9月2日に採水した サンプルの $\mathrm{Na}^{+}, \mathrm{Cl}^{-}$，界面活性斉結果と2004年12月 23 日・28日に生物調査したヤゴとの総数である . 図-2の $\mathrm{Na}^{+}, \mathrm{Cl}$ 結果と図- $110 \mathrm{Na}^{+}, \mathrm{Cl}$ 結果を比較すると，地点

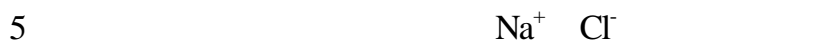
地点6以降の濃度は，ほぼ一定と同じような傾向を示す， 陰イオン界面活性斉は，地点1 4において，0 0.6mg/lと それほど濃度が変化していないが, 地点5以降は, $3.8 \mathrm{mg} / 1$ と濃度力増加している. 弚れに伴い, ヤゴの総数 も地点4では，140頭のヤゴか確認できたが，地点5では 30頭と減少している.地点 9 においては，6.2mg/l更に 上昇し，ヤゴか確認できなくなる .ヤゴか地点9で確認 できない理由は, 地点8と地点 9 は大きな地形の変化がな いことと生物か存在する場所を調査地点としていること からある程度同じ環境の比較であるので, 陰イオン界面 活性斉の増加と考えられる . 陰イオン界面活性斉㔹増加 するとき, 地点 $9 て ゙ は$ 生物か確認できないので, 陰イオ ン界面活性斉はヤゴの生存に大きく関わっていると考え られる . 大津川水系では, 陰イオン界面活性斉的 $6.2 \mathrm{mg} / 1$ になるとヤゴか確認できない .

\section{7. まとめ}

生活排水とヤゴとの関係は , 水質と生物との研究が少 ないため, 不明確な点が多い. 乥こて研究対象地は, 生 活排水とヤゴとの関係を明らかにするため, 大阪府南部 の河川において , 下流に行くにつれ生活排水量の割合が 高くなる大津川水系, 石川水系 , 環境負荷の少ない番川 と大川を選定した .

$\mathrm{Na}^{+}, \mathrm{Cl}^{-}$とヤゴの生息状況において $, \mathrm{Na}^{+}, \mathrm{Cl}$ の濃度 か増加すると，ヤゴの総数は減少する．また各種ヤゴが 2頭以上存在し，かつ $\mathrm{Na}^{+}, \mathrm{Cl}^{-}$濃度が一番高いときを生 物生息限界とすると, $\mathrm{Na}^{+}, \mathrm{Cl}$ の生物生息限界濃度力低 いのは, クロサナエ , ミルンヤンマ, 中間がニシカワト ンボ , オジロサナエ , コオニヤンマ , ヤマサナエ , 高い のは八グロトンボ , ダビドサナエであった .これまでの ヤゴの総数を種類別に考察すると, 大津川水系の上流域 は生物生息限界濃度の低いクロサナエ, ミルンヤンマ， ヤマサナエ , オジロサナエか優先種である.しかし下流 で, 生物生息限界の高いニシカワトンボやダビドサナエ , ハグロトンボが優先種になっている.これは大津川水系

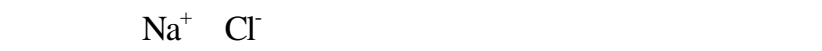
樣であった . さらに生活排水成分である陰イオン界面活

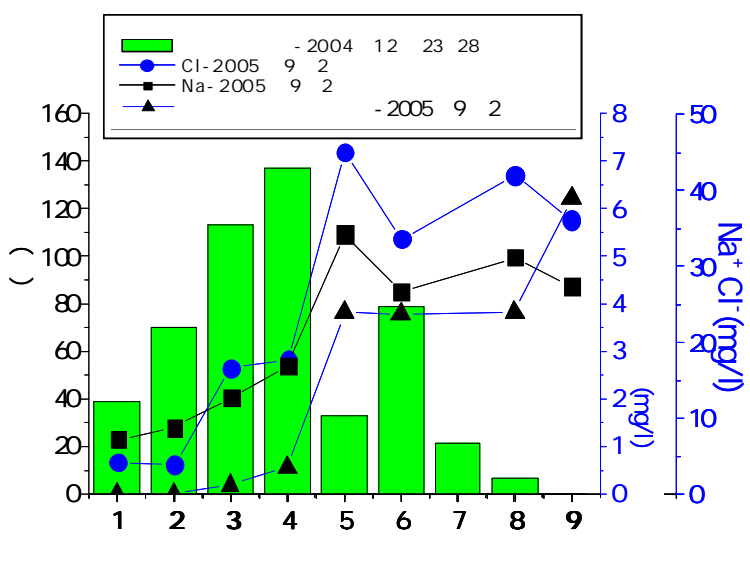

图-11 大津川水系の $\mathrm{Na}^{+}, \mathrm{a}^{-}$, 陰イオン界面活性斉と ヤゴの総数

性剂とヤゴの総数との関係をみると，ヤゴの確忍できな い地点では陰イオン界面活性斉浱度が6.2mg/l急激に増 加しており，生活排水の影響が大きいと考えられる .

\section{参考文献}

1) 坂口洋一: 循環共存型社会の環境法, 青木書店 , pp . 102103,2002 .

2) 桜井善雄 : 水辺の環境学-生き物との共存, 新日本出版, pp . 48-52, 190-193, 1992.

3）養父志乃夫 : 田んぼビオトープ入門-豊かな生き物が作る 快適農村環境，(社) 農山漁村文化協会, pp . 140-143, 2005 .

4) 井伊博行, 谷口正伸, 平田健正, 石塚正秀, 窪原拓馬, 伊勢達男, 宮川勇二 : 大和川のBOD, アンモ二ア態窒素, 陰イオン界面活性斎濃度の季節変動と光の原因について, 水工学論文集46巻, pp . 235-240, 2002 .

5) 谷口正伸, 井伊博行, 平田健正, 石塚正秀 : 大和川におけ る水温を考慮したBOD負荷量の推定, 水工学論文集49巻, pp . 1555-1560, 2005 .

6) 大阪府河川室 : http//www . pref . osaka . jp/kasen/index.html .

7) 井伊博行, 平田健正, 長谷部正彦, 江種伸之, 坂本康, 夈川高德, 西山幸治, 酒井信行, 堀井壮夫 : 環境同位体及 び化学組成からみた石川流域の河川水と地下水の起源につ いて, 水工学論文集43巻, pp . 205-210, 1999 .

8) 谷口正伸, 井伊博行, 平田健正, 石塚正秀: 大和川の生活 排水起源物質の河川内ての变化, 水工学論文集48巻, pp. 1465-1470, 2004.

9) 石塚正秀, 井伊博行, 堤久行, 平田健正 : 和泉山地小流域 における地表水の水質特性, 水工学論文集45巻, pp . 1015$1020,2001$.

10）建設省(国土交通省)大和川工事事務所 : 水生生物自然観察 ガイド, pp . 7-10, 1998 .

11）国土交通省近畿地方整備局近畿技術事務所 : 水質調査の基 礎知識, p . 74,2003 .

(2005 . 9 . 30受付) 